\title{
sciendo
}

Current Issues in Pharmacy and Medical Sciences

Formerly ANNALES UNIVERSITATIS MARIAE CURIE-SKLODOWSKA, SECTIO DDD, PHARMACIA

journal homepage: http://www.curipms.umlub.pl/

\section{The bone strengthening effects of propolis in ovariectomized female white rats as models for postmenopause}

\author{
Dian Ayu Jumita ${ }^{\star}{ }^{\circ}$, Almahdy Almahdy $^{\oplus}$, Rahmad Abdillah $^{\oplus}$, Fiony Syahputri
}

Departement Pharmacology Faculty of Pharmacy, University of Andalas, Padang, West Sumatera, Indonesia

\begin{tabular}{l}
\hline ARTICLE INFO \\
\hline Received 13 October 2020 \\
Accepted 15 July 2021
\end{tabular}

Keywords:

osteoporosis,

propolis,

impact strength,

menopause,

ovariectomy

\begin{abstract}
Osteoporosis is a bone disease characterized by decreased quality and strength of bones so that it becomes porous and fracture. Propolis is known to have many pharmacological activity, including an anti-osteoporosis effect. This study aims to determine the effect of propolis administration and the effects of propolis dosage variation in preventing osteoporosis based on the strength value of femur bone impact in female white rats in the form of an ovariectomy postmenopausal model. The rats were divided into 5 groups: positive control group (subjected to ovariectomy), negative control group (not subjected to ovariectomy, and treatment groups that were subjected to ovariectomy and given propolis at a dose of $180 \mathrm{mg} / \mathrm{kg} \mathrm{BW}$, dose $360 \mathrm{mg} / \mathrm{kg}$ BW and dose $720 \mathrm{mg} / \mathrm{kg}$ BW. Propolis was administered orally for 30 days. Bone impact strength testing was undertaken after 30 days using an impact testing machine. Research data were analyzed via one-way ANOVA and continued with the Duncan's Multiple Range Test. From the test results, we noted that propolis administration had an effect on the value of bone strength, with the dose of $720 \mathrm{mg} / \mathrm{kg}$ BW and $360 \mathrm{mg} / \mathrm{kg}$ BW having a significant effect, compared with others. With an increase in dose, propolis can provide an increase in the value of bone strength in rat bones.
\end{abstract}

\section{INTRODUCTION}

Osteoporosis is a disease characterized by abnormalities of bone tissue and changes in bone microarchitecture that can affect the strength of bone impact and cause fractures [1]. It is estimated to affect 200 million women worldwide - about one-tenth of all women aged 60 , one-fifth of all women aged 70, two-fifths of all women aged 80, and twothirds of all women aged 90. Around the world, one in every three women over the age of 50 will experience osteoporosis fractures, as will one in every five males over the age of 50 [2]. This disease often occurs especially in women who are menopausal. Two out of five women in Indonesia have a greater risk of osteoporosis [2,3].

Women have a risk of decreasing bone mass faster than men $[5,6]$. This is due to the reduced production of the estrogen hormone, especially in women who have experienced menopause $[6,7]$. This hormone is very necessary in the formation of osteoblasts and the prevention of the activity and division of osteoclast cells. Its activity is against osteoclast receptors $[7,8]$.

\footnotetext{
* Corresponding author

e-mail: dianayujuwita@phar.unand.ac.id
}

A commonly used herbal medicines is propolis. Propolis is a natural resin or gum substances collected by bees from exudates of certain tree species, with source determining its chemical composition. One of its pharmacological effects can prevent osteoporosis [10]. The main components of flavonoids and phenolic acids in propolis are known to enhance bone health [11].

Flavonoid compounds contained in propolis include pinocembrin, quercetin, naringin, galanin and chrysin. Phenolic acid compounds include Caffeic Acid Phenethyl Ester (CAPE) [12]. Flavonoids can promote bone health by five reaction mechanisms, namely, reducing bone resorption through antioxidant activity, anti-inflammatory activity, increased osteoblastogenesis activity, suppression of osteoclastogenesis activity, and increased osteo immunologicals activity [13]. Flavonoid activity of antioxidants, namely flavonoids, will increase the differentiation of osteoblasts and decrease apoptosis from these cells by enhancing the effect of bone-forming enzymes such as Alkaline Phosphatase, collagen I and other bone matrix proteins. In osteoclasts, flavonoids will reduce its differentiation and increase its apoptosis by reducing the amount of Receptor Activator of Nuclear factor Kappa-B Ligand (RANKL), as well as 
by limiting the amount of Acid Phosphatase and Cathepsin $\mathrm{K}$ protease. In osteocyte cells, flavonoid compounds will decrease RANKL, increase the production of Osteoprotegerin (OPG) and decrease Sclerostin and Dicckoph [14]. High numbers of osteoclasts result in the risk of osteoporosis [15].

Propolis is easily found in Indonesia and its use as herbal medicine is widely practiced. However, for the full understanding of the osteoporosis effect, research is still limited. Hence, it is necessary to undertake anti-osteoporosis research with regard to propolis administration. In our work, we did so by administering various doses of propolis to ovariectomized female white rats, and measuring the strength of bone impact using the Impact Testing Machine.

\section{MATERIALS AND METHODS}

This study was conducted at the Pharmacology Laboratory, Faculty of Pharmacy and the Mechanical Metallurgy Laboratory of Mechanical Engineering Department, Faculty of Engineering, Andalas University, Padang, West Sumatra.

The experimental animals used were 25 female white Wistar rats with 150-200 gram weight and 3 months of age. All experiments were carried out according to the National Institute of Health Guidelines for the care and use of laboratory animals and the European Council Directive on 24 November 1986 for Care and Use of Laboratory Animals (86/609/EEC), and approved by The Committee of Research and Ethics in the Faculty of Medicine, Andalas University (No. 146/KEP/FK/2020). The sample used is the brand " $\mathrm{X}$ " propolis concentration of $150 \mathrm{mg} / \mathrm{mL}$, with different doses.

The animals were first acclimatized for 7 days, then ovariectomy was performed on 20 rats. The rats were divided into five treatment groups, namely, negative control group, positive control group and three treatment groups (dose180 $\mathrm{mg} / \mathrm{kgBW}, 360 \mathrm{mg} / \mathrm{kgBW}$ and $720 \mathrm{mg} / \mathrm{kgBW}$ ). Observations from ovariectomy procedure were carried out for 1 day ( 24 hours), then propolis doses were given according to the treatment group.

Group I were ovariectomy rats and administered propolis at a dose of $180 \mathrm{mg} / \mathrm{kg}$ BW. Group II were ovariectomy rats and administered propolis at a dose of $360 \mathrm{mg} / \mathrm{kg} \mathrm{BW}$, Group III were ovariectomy rats and administered propolis at a dose of $720 \mathrm{mg} / \mathrm{kg} \mathrm{BW}$. Group IV were the negative control, non-ovariectomy rats only given food and drink. Group V were the positive control, ovariectomy was performed but the rats were not adminstrated propolis. All group were treated for 30 days.

On the 31st day, the rats were killed and dissected and the right femur was collected and stored in 10\% formaldehyde solution. Each rat was tested for only 1 bone. The impact strength of the bone were measured using the Impact Testing Machine Setra BL-4100L.

Femur bone retrieval was carried out for 5 days. The time of taking the femur bone until the impact test was carried out was 1-14 days after the femur bone was taken. The impact strength was calculated by comparing the impact energy obtained with the cross-sectional area of the sample that was previously measured. All data was analyzed via one-way ANOVA. Differences between measurements were considered as significant when $p<0.05$. Duncan's Multiple Range test were used to statistically verify the results presented in this study.

\section{RESULTS AND DISCUSSION}

The results obtained from the rat bone impact strength are shown in Table 1 . The analysis obtained a significance value of $p<0.05$, meaning that there are significant results in the treatment groups. Based on the results, we found that the average impact strength is quite diverse. In the negative control group, the mean value of bone impact strength showed the highest number $-3.9655 \mathrm{~J} / \mathrm{mm}^{2}$. In the positive control group, the value of bone impact strength (in general) had the lowest value $-3.2231 \mathrm{~J} / \mathrm{mm}^{2}$.

Table 1. Results of femoral bone impact strength from treatment group

\begin{tabular}{|c|c|c|c|c|c|}
\hline \multirow{2}{*}{ Treatment Group } & \multicolumn{5}{|c|}{ Impact Strength of Bone $\left(\mathrm{J} / \mathrm{mm}^{2}\right)$} \\
\cline { 2 - 6 } & Animal 1 & Animal 2 & Animal 3 & Animal 4 & Animal 5 \\
\hline Dose $180 \mathrm{mg} / \mathrm{kg} \mathrm{BB}$ & 3.2513 & 3.3201 & 2.9586 & 3.5735 & 3.3470 \\
\hline Dose $360 \mathrm{mg} / \mathrm{kg} \mathrm{BB}$ & 3.2749 & 3.7658 & 3.4568 & 3.4827 & 3.5044 \\
\hline Dose $720 \mathrm{mg} / \mathrm{kg} \mathrm{BB}$ & 3.6364 & 3.9966 & 3.6316 & 3.7607 & 4.0270 \\
\hline Negative control & 4.3808 & 4.2454 & 4.0286 & 3.4327 & 3.7399 \\
\hline Positive control & 3.4568 & 3.3867 & 3.7384 & 2.4422 & 3.0982 \\
\hline
\end{tabular}

In the treatment group with a dose of $180 \mathrm{mg} / \mathrm{kg}$ body weight, $360 \mathrm{mg} / \mathrm{kg}$ body weight, and $720 \mathrm{mg} / \mathrm{kg}$ body weight, the average strength of bone impact values was $3.2901 \mathrm{~J} / \mathrm{mm}^{2}, 3.4969 \mathrm{~J} / \mathrm{mm}^{2}$, and $3.8105 \mathrm{~J} / \mathrm{mm}^{2}$, respectively (Table 2 and Figure 1). In order to see the difference in each treatment group, Duncan's test was applied.

Table 2. Mean value of femoral bone impact strength from five treatment groups

\begin{tabular}{|l|c|}
\hline \multicolumn{1}{|c|}{ Treatment Group } & Mean value of Impact Strength \pm SE \\
\hline Dose $180 \mathrm{mg} / \mathrm{kg} \mathrm{BB}$ & $3.2901 \pm 0.2213^{\mathrm{a}}$ \\
\hline Dose $360 \mathrm{mg} / \mathrm{kg} \mathrm{BB}$ & $3.4969 \pm 0.1757^{\mathrm{b}}$ \\
\hline Dose $720 \mathrm{mg} / \mathrm{kg} \mathrm{BB}$ & $3.8105 \pm 0.1912^{\mathrm{b}}$ \\
\hline Negative control & $3.9655 \pm 0.3839$ \\
\hline Positive control & $3.2231 \pm 0.4925^{\mathrm{a}}$ \\
\hline
\end{tabular}

Note: a = significant difference found compared to negative control $(p<0.05) ; b=$ no significant difference compared to negative control $(p>0.05)$

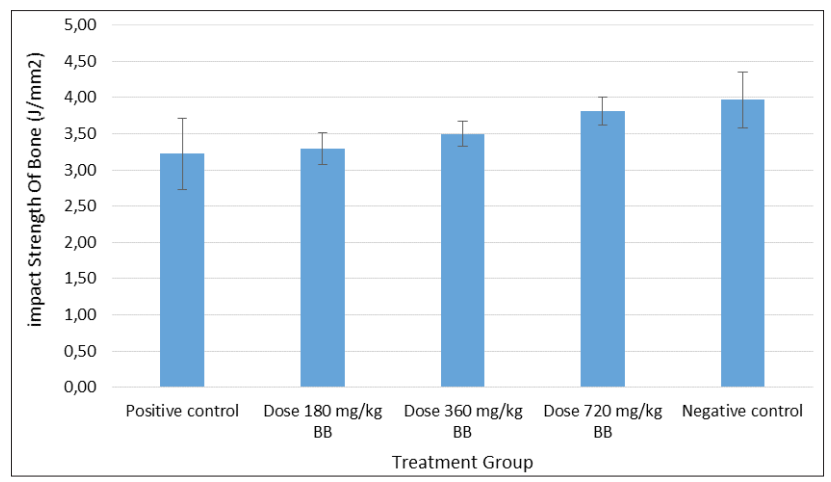

Figure 1. A bar chart of the average strength values of femoral bone impact strength from five treatment groups 
Based on the Duncan's test results as seen in Table 2, three different subsets were obtained. In the first subset, there was a positive control group, a dose group of 180 $\mathrm{mg} / \mathrm{kg}$ body weight and a dose group of $360 \mathrm{mg} / \mathrm{kg}$ body weight, with a significant value of $0.215(\mathrm{p}>0.05)$. In the second subset, there was a dose group of $360 \mathrm{mg} / \mathrm{kg}$ body weight and a dose group of $720 \mathrm{mg} / \mathrm{kg}$ body weight, with a significant value of $0.135(\mathrm{p}>0.05)$. In the third subset there was a dose of $720 \mathrm{mg} / \mathrm{kg}$ BW and negative control, meaning that the two treatment groups were not significantly different, having a significant value of $0.450(p>0.05)$.

On assessing the results of observations from the average impact strength values, we can say that we obtained quite a diverse set of data between the types of treatments given. From these values, it can be concluded that there are differences in the average value of bone impact strength from negative controls, a dose of $180 \mathrm{mg} / \mathrm{kg} \mathrm{BW}$, a dose of 360 $\mathrm{mg} / \mathrm{kg} \mathrm{BW}$, a dose of $720 \mathrm{mg} / \mathrm{kg} \mathrm{BW}$ and positive control. It should be noted that the value of bone impact strength is influenced by the physiology of the body, bone size, number of bone-forming cells, and the amount of bone mineralization.

In bone strength testing using an impact testing machine, we saw differences in the average impact strength values of the various test groups, when compared with the control group. In the negative control group (not on ovariectomy and not given propolis), the average value of bone impact strength showed the highest rate of $3.9655 \mathrm{~J} / \mathrm{mm}^{2}$. This is because the experimental animals used were not in menopause condition, thuse the estrogen hormone was still being produced by the ovaries, so the highest bone impact strength values are generally found in this group. In the positive control group (in ovariectomy, but not given propolis), the value of bone impact strength, in general, has the lowest value of $3.2231 \mathrm{~J} / \mathrm{mm}^{2}$. According to Mustafa S. (2011), this is caused by a decrease in estrogen hormone content due to menopause - a factor that triggers osteoblast cell formation in the myeloid tissue of red marrow [16]. Herein, bone strength is influenced by the bone quality, bone density and bone remodelling process played by osteoclasts and osteoblasts [17].

In the treatment group with a dose of $180 \mathrm{mg} / \mathrm{kg} \mathrm{BW}$, the average bone impact strength of $3.2901 \mathrm{~J} / \mathrm{mm}^{2}$ was not significantly different from positive control, and there was only a slight increase in bone strength when propolis was administered. According to Domazetovic (2017), propolis works as an antioxidant. This has the opposite effect of Reactive Oxidative Stress (ROS) [14].

At a dose of $360 \mathrm{mg} / \mathrm{kg} \mathrm{BW}$ group, the average value of bone impact strength was $3.4969 \mathrm{~J} / \mathrm{mm}^{2}$. This dose is a general dose commonly prescribed to treat osteoporosis, and the value of bone impact strength is quite different when compared to positive control and the dose of $180 \mathrm{mg} / \mathrm{kg}$ body weight. It can be said that it has a fairly maximal effect. In postmenopausal women, the amount of estrogen will decrease because the ovaries (which are one of the producers of this hormone) are no longer functioning. The estrogen hormone plays a key role in maintaining the balance in the number of osteoblasts and osteoclasts in the bone [18].
The dose of $720 \mathrm{mg} / \mathrm{kg} \mathrm{BW}$ (which is the highest dose given) shows a significantly higher impact strength value of $3.8105 \mathrm{~J} / \mathrm{mm}^{2}$. This is higher than the positive control and is also higher than that of a dose of $180 \mathrm{mg} / \mathrm{kg} \mathrm{BW}$ and $360 \mathrm{mg} / \mathrm{kg} \mathrm{BW}$, but lower than the outcome of the negative control. At a dose of $720 \mathrm{mg} / \mathrm{kg} \mathrm{BW}$, this protective effect comes about due to maintenance of the balance of bone remodelling so that the process of the bone formation increases. This can be seen from its value - which is almost close to the negative control. Estrogen plays a very important role in bone metabolism by allowing a balance of bone-forming cells (osteoblasts) and bone-destroying cells (osteoclasts) [19].

In research conducted by Al-Qtaitat (2014), the administration of propolis can maintain the stability of the skeletal bones of experimental animals that are ovariectomized. This is because the flavonoid compounds in propolis have similar characteristics to selective estrogen receptor modulators (SERMs) that can prevent bone resorption by osteoclasts and increase the formation of osteoblasts so that they can prevent osteoporosis [10]. Herein, it should be recalled that bone impact strength is influenced by mineral content in bone, bone size, bone structure, and balance of bone remodelling by osteoblasts and osteoclasts [20].

After applying the Duncan Multiple Range test, three different subsets were obtained. If the treatment group is in the same subset, this means that the group is not significantly different from the $\mathrm{p}$ value $>0.05$. The Duncan test indicates that a significant difference exists in the outcome of doses of $180 \mathrm{mg} / \mathrm{kg}$ body weight and doses of $720 \mathrm{mg} / \mathrm{kg}$ body weight, meaning that the effect of these two treatment groups was significantly different with regard to the strength of the rat bone impact.

As bone strength and hardness are also determined by calcium phosphate, collagen fibril, and other mineral crystal availability, an increase in the impact strength of femur bones in the experimental animals given propolis at different doses is, we believe, brought about by the amount of flavonoids and polyphenols that are present in the rat body. These have antioxidant activity [21]. Flavonoids in propolis like pinocembrin, naringenin, CAPE, myricetin, etc. are compounds that are noted for having antioxidant activity, as opposed to ROS, where antioxidants will increase osteoclastogenesis [22].

\section{CONCLUSION}

In the form of a postmenopausal ovariectomized model, administration of propolis at a dose of $360 \mathrm{mg} / \mathrm{kg} \mathrm{BW}$, and a dose of $720 \mathrm{mg} / \mathrm{kg}$ BW demonstrate a bone strengthening effect on femur bones in female white rats.

\section{CONFLICTS OF INTERESTSTATEMENT}

The authors declare that they have no known competing financial interests or personal relationships that could have appeared to affect the objectivity and credibility of the work reported in this paper. 


\section{STATEMENT OF THE SOURCES OF FUNDING}

The authors are thankful to the Faculty of Pharmacy, Andalas University, which has provided financial support and facilities for conducting this research.

\section{ORCID iDs}

Dian Ayu Juwita (Dhttps://orcid.org/0000-0003-2078-2049 Almahdy Almahdy (Dhttps://orcid.org/0000-0003-4311-6233 Rahmad Abdillah (1)https://orcid.org/0000-0001-9072-2522

\section{REFERENCES}

1. Ohta H, Solanki J. Incorporating bazedoxifene into the treatment paradigm for postmenopausal osteoporosis in Japan. Osteoporos Int. 2015;26(3):849-63.

2. Kanis JA, Johnell O, Oden A, Sernbo I, Redlund-Johnell I, Dawson A, et al. Long-term risk of osteoporotic fracture in Malmo. Osteoporos Int. 2000;11(8):669-74.

3. Ginta Siahaan, Efendi Nainggolan DL. Hubungan Komposisi Tubuh dengan Kepadatan Tulang Wanita Usia Subur di Kota Bandung. Indones J Hum Nutr. 2015;2(1):48-59.

4. Sozen T, Ozisik L, Calik Basaran N. An overview and management of osteoporosis. Eur J Rheumatol. 2017;4(1):46-56.

5. Ermawati DH. Menopause and biopsychosocial factors associated with quality of life in women in Surakarta, Central Java. J Matern Child Heal. 2018;03(02):119-27.

6. Gambacciani M, Biglia N, Cagnacci A, Caruso S, Cicinelli E, De Leo $\mathrm{V}$, et al. Menopause and hormone replacement therapy: The 2017 recommendations of the Italian menopause society. Minerva Ginecol. 2018;70(1):27-34.

7. Thulkar J, Singh S. Overview of research studies on osteoporosis in menopausal women since the last decade. J Midlife Health. 2015;6(3):104.

8. Khosla S, Oursler MJ, Monroe DG. Estrogen and the skeleton. Trends Endocrinol Metab. 2012;23(11):576-81.

9. Stavros C M, O'Brien CA, Almeida M. The role of estrogen and androgen receptors in bone health and disease. Nat Rev Endocrinol. 2013;9(12):699-712.

10. Al-Qtaitat A. Bioactive propolis and bone loss reduction in an ovariectomized rat model of hypogonadal osteoporosis. Am J Biosci. 2014;2(6):217.
11. Wagh VD. Propolis: A wonder bees product and its pharmacological potentials. Adv Pharmacol Sci. 2013. https://doi.org/ $10.1155 / 2013 / 308249$

12. Kuropatnicki AK, Szliszka E, Krol W. Historical aspects of propolis research in modern times. Evidence-based Complement Altern Med. 2013. https://doi.org/10.1155/2013/964149

13. Dudarić L, Fužinac-Smojver A, Muhvić D, Giacometti J. The role of polyphenols on bone metabolism in osteoporosis. Food Res Int. 2015;77:290-8.

14. Domazetovic V, Marcucci G, Iantomasi T, Brandi ML, Vincenzini MT. Oxidative stress in bone remodeling: role of antioxidants. Clin Cases Miner Bone Metab. 2017;14(2):209.

15. Florencio-Silva R, Rodrigues da Silva Sasso G, Sasso-Cerri E, Jesus Simões M, Sérgio Cerri P. Biology of bone tissue: structure, function, and factors That influence bone cells. Hindawi Publ Corp BioMed Res Int. 2015;7(1):1-17.

16. Singh D, Sanyal S, Chattopadhyay N. The role of estrogen in bone growth and formation: Changes at puberty. Cell Health Cytoskelet. 2011;3(1):2-12.

17. Tavera Ruiz CG, De La Torre-Ibarra MH, Flores-Moreno JM, Frausto-Reyes C, Mendoza Santoyo F. Cortical bone quality affectations and their strength impact analysis using holographic interferometry. Biomed Opt Express. 2018;9(10):4818.

18. Puspita EM, Siregar MFG, Adenin I. Correlation of estradiol serum levels with classification of osteoporosis risk OSTA (Osteoporosis Self-Assessment Tools for Asian) in menopause women. Bali Med J. 2017;6(1):52.

19. Nur H, Toraman NF, Arica Z, Sarier N, Samur A. The relationship between body composition and bone mineral density in postmenopausal Turkish women. Rheumatol Int. 2013;33:607-12.

20. Yudaniayanti IS, Primarizky H, Nangoi L, Yuliani GA. Protective effects of honey by bees (Apis dorsata) on decreased cortical thickness and bone impact strength of ovariohysterectomized rats as models for menopause. Vet World. 2019;12(6):868-76.

21. An J, Hao D, Zhang Q, Chen B, Zhang R, Wang Y, et al. Natural products for treatment of bone erosive diseases: The effects and mechanisms on inhibiting osteoclastogenesis and bone resorption. Int Immunopharmacol. 2016;36:118-31.

22. Silva-Carvalho R, Baltazar F, Almeida-Aguiar C. Propolis: A complex natural product with a plethora of biological activities that can be explored for drug development. Evidence Based Complement Altern Med. 2015;2015:206439. 